\title{
Congratulatory Remarks: Minister of Education and Science, and Technology
}

\author{
Ju Ho Lee
}

First of all, congratulations on the opening of the 12th International Congress on Mathematical Education.

I am glad that this important math event is being held in Korea this year.

Also, it is a great pleasure to welcome math education researchers and math teachers from more than 100 countries.

With the aim of transforming Korea into a nation of great science and technology capacity, and a nation of outstanding human talent, the Ministry of Education, Science and Technology of Korea is focusing on three important points in designing and implementing its policies.

The three points are "creativity", "convergence", and "human talent". Creativity enables us to think outside the box, convergence allows us to go beyond the traditional boundaries between disciplines, and finally human talent builds the very foundation that make all these possible.

Without a doubt, these are the most essential elements in today's knowledgebased society.

Math is the very subject that can foster much needed creativity and convergence, and is becoming a core factor in raising national competitiveness.

Math is behind everything.

The ICT revolution would have been impossible without the binary system.

The technology behind the CT scans can be traced back to simultaneous equations.

Open Access This chapter is distributed under the terms of the Creative Commons Attribution Noncommercial License, which permits any noncommercial use, distribution, and reproduction in any medium, provided the original author(s) and source are credited.

An erratum of the original chapter can be found under DOI 10.1007/978-3-319-12688-3_80

J.H. Lee $(\bowtie)$

Former Minister of Education, Science and Technology, KDI School

of Public Policy and Management, Seoul, Republic of Korea

(C) The Author(s) 2015

S.J. Cho (ed.), The Proceedings of the 12th International Congress

on Mathematical Education, DOI 10.1007/978-3-319-12688-3_4 